\title{
KNJIŽNICA DUGAVE \\ KAO MJESTO SUSRETA RAZLIČITIH SVJETOVA
}

\author{
THE DUGAVE LIBRARY AS \\ THE MEETING POINT OF DIFFERENT WORLDS
}

\section{Tihana Rašeta}

Knjižnice grada Zagreba

tihana.raseta@kgz.hr

Sanja Lautenbach-Huzjak

Knjižnice grada Zagreba

sanja.lautenbach.huzjak@kgz.hr

UDK / UDC 025.5(497.5 Zagreb):314.7-054.7

Stručni rad / Professional paper

Primljeno / Received: 6. 11. 2018.

Prihvaćeno / Accepted: 28. 1. 2019.

\section{Sažetak}

Cilj. Izložiti rad djelatnika u Knjižnici Dugave koji se odnosi na rad s migrantima i izbjeglicama.Također, pokazati odnos lokalne zajednice prema novim stanovnicima te njihovu spremnost za upoznavanje novih kultura. Prikazati uključivanje svih odjela unutar knjižnice te navesti različite akcije ujedinjene oko istog cilja - inkluzije migranata i izbjeglica u lokalnu zajednicu.

Pristup/metodologija. Kronološki prikaz suradnje knjižnice s drugim institucijama koje su željele pomoći u novonastaloj situaciji.

Rezultati. Kronološki prikaz pokazuje koliko se suradnja Knjižnice Dugave širila na različite institucije i pojedince iz godine u godinu. Spremnost lokalne zajednice da dozna i upozna nove stanovnike i zemlje iz kojih dolaze. Stručno praćenje te studije vezane uz ovu temu ukazuju na daljnju potrebu i djelovanje knjižnice kao spone između lokalne zajednice i migranata te između institucija i migranata.

Vjesnik bibliotekara Hrvatske 61, 2(2018), 403-418

ISSN 0507-1925

(C) VBH 2018. 
Originalnost/vrijednost. Rad je prvi u Republici Hrvatskoj koji se bavi prikazom rada s migrantima unutar knjižnice te pokazuje dobru suradnju s ostalim institucijama. Prikazan je i rad na senzibiliziranju lokalne zajednice za migrante. Na nekoliko različitih primjera dane su smjernice za rad u drugim knjižnicama ukoliko se nađu u istoj situaciji.

Ključne riječi: Crveni križ, Knjižnica Dugave, lokalna zajednica, migranti, senzibilizacija

\section{Abstract}

Objective. The paper aims to present the Dugave Library in Zagreb employees' work and activities related to migrants and refugees. Also, it shows the relationship of the local community to the new inhabitants and their readiness to learn about new cultures. The involvement of all library departments and various activities aimed at the inclusion of migrants into local community are described.

Approach/methodology. A chronological overview of the library's cooperation with other institutions willing to help in the new situation is presented.

Results. The chronological overview shows to what extent the cooperation of the Dugave Library has spread to other institutions and individuals from year to year. The readiness of the local community to become acquainted with the new inhabitants and the countries they come from. The expert studies show that the library should continue to act as a link between the local community and the migrants as well as between the institutions and the migrants

Originality/value. This work is the first in the Republic of Croatia to present the work with migrants in a library. It also shows a good cooperation with other institutions. Furthermore, it describes the work and sensitizing the local community to the needs of the migrants. Several examples have been given to provide some guidelines on how other libraries should act in a similar situation.

Keywords: The Dugave library in Zagreb, local community, migrants, Red Cross, sensitizing

\section{Uvod}

Agenda Ujedinjenih naroda za održivi razvoj 2030 sadrži 17 globalnih ciljeva i 169 podciljeva održivog razvoja koji obuhvaćaju sva područja važna za život, djelovanje i opće dobro svakog pojedinca te utječu na razvoj društva u cjelini. Glavni aspekti koje IFLA zagovara u Ujedinjenim narodima jesu: osiguravanje pristupa informacijama i zaštita temeljnih sloboda u skladu s nacionalnim za- 
konodavstvom i međunarodnim sporazumima, očuvanje kulturne baštine, opća pismenost, učenje i obrazovanje te dostupnost i korištenje informacijsko-komunikacijske tehnologije. ${ }^{1}$

Knjižnice svojim djelovanjem i programskim okvirima podržavaju sve globalne ciljeve te su spremne prihvatiti ulogu partnera u njihovu ostvarivanju. Omogućavanjem općeg pristupa informacijama i znanju knjižnice doprinose održivom razvoju i kvaliteti života svih svojih korisnika i lokalne zajednice.

Dolaskom sve većeg broja tražitelja međunarodne zaštite u Republiku Hrvatsku te njihovim smještajem u Prihvatilište za tražitelje međunarodne zaštite Zagreb, koje se nalazi u Dugavama, Knjižnica Dugave aktivno se uključila u proces integracije novopridošlih susjeda, zajedno s mrežom suradnika i lokalnom zajednicom. Bio je to novi izazov i prilika za učvršćivanje uloge knjižnice u lokalnoj zajednici te ostvarivanje ciljeva koji doprinose održivom razvoju i kvalitetnom životu svih njezinih korisnika.

Od početka ljudske civilizacije ljudi su selili, migrirali, ali isto tako i bježali od raznih nedaća koje su ih snalazile. ${ }^{2}$ Postoje pisani tragovi o migracijama u Mezopotamiji, Perziji i Grčkoj, gdje se spominju poznatiji građani koji su doselili iz drugih zemalja u potrazi za poslom te se također spominju migracije stanovnika zbog velikih prirodnih katastrofa i ratova. Još se u starom Egiptu spominju velike poplave Nila i ratni sukobi koji su primorali lokalne stanovnike da se presele u sigurnije zemlje. U posljednjih nekoliko godina također svjedočimo izbjegličkoj krizi u svijetu koja je jedna od najvećih od Drugog svjetskog rata. Tijekom izbjegličke krize milijuni ljudi, uglavnom iz Afrike i s Bliskog istoka, morali su napustiti svoje domove jer su im u zemljama iz kojih dolaze životi bili ugroženi zbog ratova, proganjanja zbog nacionalnosti i religijskih uvjerenja te zbog teških ekonomskih prilika. Sve veći broj izbjeglica traži sklonište u zemljama Europe. ${ }^{3}$ Moramo naglasiti razliku između migranata i izbjeglica, jer migranti napuštaju zemlju iz razloga koji nisu povezani s progonom. Oni možda žele studirati u inozemstvu, povezati se sa svojom obitelji ili poboljšati svoje buduće ekonomske prilike, dok izbjeglice prema UN-u napuštaju svoju zemlju iz straha od progona zbog rase, nacionalnosti, pripadnosti određenoj društvenoj skupini ili političkoj opciji. ${ }^{4}$

\footnotetext{
1 Vidi Pristup i mogućnosti svima: kako knjižnice doprinose ostvarivanju Agende Ujedinjenih naroda za održiv razvoj 2030. [citirano: 2019-01-16]. Dostupno na: https://www. hkdrustvo.hr/hr/izdanja/kategorija/elektronicka?fbclid=IwAR3OpnNa6NFN_n5yNBKbXTtvb8AB0f5arjpm5gJG_xvg6tjiZJkJUreOMY.

2 Vidi Milardović, A. Uvodna riječ. // Stranci pred vratima Europe / urednik Anđelko Milardović Zagreb: Pan Liber: Institut za europske i globalizacijske studije, 2014. Str. 9.

3 Kingsley, P. Nova Odiseja: priča o europskoj izbjegličkoj krizi. Zagreb: Profil knjiga, 2016. Str. 305-306.

4 Lalić Novak, G.; R. Kraljević. Zaštita izbjeglica i ranjivih skupina migranata: priručnik za edukatore. Zagreb: Hrvatski Crveni križ, 2014. Str. 16-17. [citirano: 2019-01-09]. Dostupno
} 
Izbjeglica ne uživa zaštitu svoje države, a progonom mu može prijetiti i vlastita vlada. EU od svog osnivanja 1992. predstavlja supstitucionalni prostor koji je osigurao mir i ekonomski prosperitet, a to je razlog zbog kojeg migranti i izbjeglice često odabiru Europu kao glavni cilj svojeg putovanja. Međutim zbog velikog broja migranata i izbjeglica te pojave terorizma, nasilja i organiziranog kriminala pokazala se potreba za uvođenjem novih europskih programa sigurnosti. ${ }^{5}$

Kako bi se povećanom suradnjom unutar Europske unije onemogućilo djelovanje kriminalnih mreža koje iskorištavaju potrebe izbjeglica i migranata te spriječilo krijumčarenje i trgovina ljudima, u svibnju 2015. donesen je Europski migracijski program. Kako se situacija mijenja i postaje sve zahtjevnija te joj se ne nazire krajnje rješenje, Europska unija nastavlja donositi i druge strategije koje se odnose na sigurnost matičnih zemalja kako bi u novonastaloj situaciji zaštitila vlastite građane te je 2016. usvojena globalna strategija Europske unije za vanjsku i sigurnosnu politiku. ${ }^{6}$

Europska unija jamči sigurnost vlastitim građanima te izravno povezuje unutarnju i vanjsku sigurnost. ${ }^{7}$

\section{Knjižnice u Hrvatskoj i problemi tražitelja međunarodne zaštite}

U Republici Hrvatskoj, sukladno Zakonu o međunarodnoj i privremenoj zaštiti (NN 70/15, 127/17) ${ }^{8}$, pruža se međunarodna zaštita osobama koje mogu dokazati da su u zemlji porijekla bile osobno proganjane zbog rase, vjere, pripadnosti određenoj društvenoj skupini ili političkog mišljenja. Osobe kojima je odobrena međunarodna zaštita stječu prava i mogućnosti s područja socijalne skrbi i zdravstvene zaštite, učenja jezika i obrazovanja, smještaja, stanovanja i zapošljavanja te im se propisuju obveze jednako kao i hrvatskim državljanima. Prema izvještajima MUP-a, od 20. 6. do 30. 9. 2018. bilo je 509 podnesenih zahtjeva za traženje azila. ${ }^{9}$ Od toga je 260 muškaraca, 78 žena te 171 dijete, a $26 \%$ čine djeca mlađa od 13

\footnotetext{
na: $\quad$ https://www.hck.hr/UserDocsImages/publikacije/Priru\%C4\%8Dnici/Prirucnik\%20-\%20 Zastita\%20izbjeglica\%20i\%20ranjivih\%20skupina\%20migranata.pdf.

5 Dragović, F. Sigurnost europskih granica i migracije. Zagreb: Naklada Jesenski i Turk, 2018. Str. 94.

6 Isto, str. 97.

7 Petrović, D. Izbjeglištvo u suvremenom svijetu: od političkoteorijskih utemeljenja do biopolitičkih ishoda. Zagreb: Naklada Ljevak, 2016. Str. 407.

8 Vidi Zakon o međunarodnoj i privremenoj zaštiti: pročišćeni tekst zakona: NN 70/15,127/17. // Zakon.hr. [citirano: 2019-01-16]. Dostupno na: https://www.zakon.hr/z/798/Zakon-ome\%C4\%91unarodnoj-i-privremenoj-za\%C5\%A1titi.

9 Vidi Ministarstvo unutarnjih poslova. Statistički pokazatelji osoba kojima je odobrena međunarodna zaštita u Republici Hrvatskoj zaključno do 30.09.2018. Str. 1. [citirano: 201901-14]. Dostupno na: http://stari.mup.hr/UserDocsImages/Publikacije/2018/19-10-Statistickipokazatelji-trazitelja- medunarodne-zastite-30-09.pdf.
} 
godina. Dio djece polazi prilagođeni program školovanja koji uključuje 75 učenika. Od toga je 63 osnovnoškolske djece od 6 do 14 godina, a njih 28 učenici su Osnovne škole Gustava Krkleca koja se nalazi u naselju Travno u Novom Zagrebu, u neposrednoj blizini Hotela Porin. Učenici su smješteni u različitim razredima i programi su prilagođeni njihovim mogućnostima. Unutar škole omogućena im je i pomoć u učenju i svladavanju jezika te ostalih predmeta kako bi što prije bili u razredu sa svojim vršnjacima.

Svjesna novih izazova i trendova u knjižničarstvu s početkom dolaska izbjeglica i migranata u Republiku Hrvatsku, Knjižnica Dugave spremno se uključila u mrežu suradnika i prihvatila novu skupinu korisnika u svoje prostore.

Knjižnica Dugave nalazi se u istoimenom novozagrebačkom naselju Dugave, a u neposrednoj blizini, u istom naselju, dva kilometra od knjižnice, nalazi se bivši Hotel Porin, koji je 2013. godine postao Prihvatilište za tražitelje međunarodne zaštite.

Knjižnice Novog Zagreba već su u prošlosti imale iskustva rada s izbjeglicama, kada su tijekom devedesetih godina 20. st. u Hrvatskoj mnogi ljudi bježali iz svojih domova te su bili smješteni kao izbjeglice u stambene jedinice na području Novog Zagreba. Knjižnice Novog Zagreba tada su se uključile u programe koji su bili osmišljeni kako bi pomogli izbjeglicama da lakše prebrode teške životne situacije te da se kroz određene programe oslobode trauma koje su tada doživjeli. Prisjećajući se tog razdoblja rata, mnogi stanovnici Republike Hrvatske imaju razumijevanja za novonastalu situaciju u Europi vezanu uz izbjeglice. ${ }^{10}$

\section{Pregled suradnje Knjižnice Dugave i tražitelja međunarodne za- štite iz Prihvatilišta Zagreb od 2013. do 2018. godine}

\subsection{O Knjižnici Dugave i Prihvatilišstu za tražitelje međunarodne zaštite Zagreb}

Knjižnica Dugave nalazi se u istoimenom novozagrebačkom naselju. Dugave su jedno od najjužnijih novozagrebačkih naselja, a u sustavu su Gradske četvrti Novi Zagreb istok. Okružene su naseljima Travno na sjeveru i Sloboština na zapadu, dok je na jugu Ranžirni kolodvor. Broj stanovnika Dugava prema popisu stanovništva iz 2011. godine iznosi 10492 , a naselje se prostire na površini od 85,02 ha. ${ }^{11}$

\footnotetext{
10 Grubiša, I. Mi i oni?: kulturnoantropološko propitivanje terenskog iskustva u Slavoniji. // Kamp, koridor, granica: studije izbjeglištva u suvremenom hrvatskom kontekstu / uredile Emina Bužinkić i Marijana Hameršak. Zagreb: Institut za etnologiju i folkloristiku: Centar za mirovne studije: Fakultet političkih znanosti: Centar za istraživanje etičnosti, državljanstva i migracija, 2017. Str. 78.

11 Vidi Grad Zagreb. Mjesni odbor Dugave. [citirano 2019-01-14] Dostupno na: https://www. zagreb.hr/2-mjesni-odbor-dugave/14576.
} 
Knjižnica Dugave osnovana je krajem 1983. godine, a u studenom 1985. godine ušla je u sustav Knjižnica grada Zagreba kao ogranak Knjižnice Novi Zagreb. $\mathrm{Na}$ površini od $225 \mathrm{~m}^{2}$ smješten je Odjel za odrasle s čitaonicom, Odjel za djecu i mlade, AV-odjel, studijska čitaonica i izložbeni prostor. Usluge knjižnice koristi oko 4700 aktivnih korisnika svih dobnih skupina.

Knjižnica Dugave ima značajnu ulogu u društvenom i kulturnom životu lokalne zajednice. Djelatnici knjižnice u suradnji sa svojim stalnim i povremenim suradnicima pružaju kvalitetne programe i usluge kojima žele zadovoljiti raznolike kulturne i informacijske potrebe svojih sugrađana svih dobnih skupina.

Osim primarne djelatnosti posudbe knjižne i audio-vizualne građe, u knjižnici se mogu dobiti informacije o traženim naslovima, savjeti pri izboru građe, izbor literature za izradu domaćih zadaća, referata, seminarskih i diplomskih radova. Uz besplatan pristup internetu, korisnicima se pruža pomoć pri pretraživanju kataloga i educira ih se o načinima korištenja usluga kataloga. Na korištenje se daju zaštićene zbirke, priručna literatura, periodičke publikacije, dnevni, tjedni i mjesečni tisak. U prostoru knjižnice kontinuirano se postavljaju tematske i likovne izložbe, organiziraju se susreti, tribine, predavanja te razne pedagoško-animacijske aktivnosti za djecu i mlade.

U istom naselju, dva kilometra od Knjižnice Dugave, nalazi se bivši Hotel Porin čiji je kapacitet smještaja 600 osoba. Hotel Porin 2013. je godine u potpunosti postao Prihvatilište za tražitelje azila Zagreb. ${ }^{12}$

U prihvatilištu se obavljaju poslovi prihvata i smještaja tražitelja azila, uzimanja zahtjeva, otisaka i fotografiranja. Izrađuju se iskaznice tražitelja azila, sudjeluje se u utvrđivanju identiteta stranaca smještenih u Prihvatilištu. Skrbi se o zbrinjavanju i pružanju pomoći, organizira se prikupljanje materijalnih sredstava i osiguravaju se osnovni uvjeti za život, kontaktira se i koordinira s nadležnim tijelima i institucijama u ostvarivanju prava i pružanju potrebne skrbi tražiteljima azila.

\subsection{Odř̆ani programi u Knjižnici Dugave u okviru petogodišnje surad- nje s traz̆iteljima međunarodne zaštite}

\subsubsection{Izložbe}

Sredinom lipnja 2013. godine, uz Svjetski dan izbjeglica, započinje suradnja Knjižnice Dugave, djelatnika Hrvatskog Crvenog križa i tražitelja međunarodne zaštite iz Prihvatilišta Zagreb s ciljem poticanja aktivnijeg uključivanja tražitelja azila u širu zajednicu i senzibilizacije stanovništva u lokalnoj zajednici na novopridošle susjede.

12 Vidi Hrvatski Crveni križ. Podrška tražiteljima međunarodne zaštite. [citirano: 201901-14].Dostupno na: https://www.hck.hr/sto-radimo/azil-i-migracije/podrska-traziteljimamedjunarodne-zastite/210. 
U realizaciji zadanog cilja organizirani su brojni susreti i aktivnosti namijenjeni našim korisnicima, ali i lokalnom stanovništvu. ${ }^{13}$

Na prvom dvodnevnom susretu u Knjižnici Dugave s tražiteljima azila, uz uvodne riječi Mirele Jozić iz Hrvatskog Crvenog križa, tražitelji azila predstavili su nam običaje i kulturu zemalja iz kojih dolaze. ${ }^{14}$ Istovremeno je otvorena Izložba slika i rukotvorina tražitelja azila, nastalih na kreativnim radionicama u prihvatilištu koje vodi gospođa Ljubica Vlašić, djelatnica Hrvatskog Crvenog križa. Do danas je u Knjižnici Dugave postavljeno 5 izložbi rukotvorina tražitelja azila i slika M. Katouzifar i S. Shirzada, jedna izložba dječjih crteža i jedna izložba fotografija pod nazivom Balkanska ruta. Autori fotografija bili su K. Mijić, I. Malle, sirijski fotograf, N. Vudrić i A. Majić, volonteri Hrvatskog Crvenog križa. Fotografije su nastale tijekom najvećeg izbjegličkog vala u Harmici, Botovu te unutar izbjegličkih kampova. ${ }^{15} \mathrm{Na}$ Odjelu za djecu i mlade Knjižnice Dugave na inicijativu Udruge Balkon postavljena je izložba radova djece migranata nastalih na njihovu migrantskom putu i u privremenom smještaju u prihvatilištu. Izložba pod naslovom Sadašnjost, prošlost, budućnost dio je međunarodnog projekta Colours of a Journey. Izloženo je 15 crteža djece od 6 do 18 godina, kako bi nam ispričali svoju priču kroz likovne radove iz razdoblja prošlosti, sadašnjosti i budućnosti. Osim izložbenog prostora, Knjižnica Dugave ponudila je niz aktivnosti, uz razgledavanje izložbe u sklopu projekata Cronauti i KLJUČ do znanja, koji promiču vrijednosti znanja, tolerancije i kulture čitanja. ${ }^{16}$

Na Odjelu za odrasle priređeno je pet svečanih otvorenja izložbi na kojima je sudjelovalo 255 posjetitelja. Kako bi što lakše prevladali jezične barijere te olakšali komunikaciju s lokalnim stanovništvom, tražitelji azila priredili su uz druženje nekoliko jednostavnijih jela i pića, tradicionalnih u zemljama iz kojih dolaze. ${ }^{17}$

Uz izložbu radova tražitelja azila održana je i kreativna radionica za naše odrasle članove. Na radionicama su se izrađivali predmeti od novinskog papira. Radionice je vodio K. Khan, tražitelj azila iz Pakistana (Balučistana). ${ }^{18}$

13 Prema godišnjim Izvještajima o radu u Knjižnici Dugave od 2013. do 2018. godine. Izvještaji su dostupni u arhivi Knjižnice Dugave.

14 Vidi Hrvatski Crveni križ. Obilježen Svjetski dan izbjeglica - 20. lipnja. [citirano: 2019.01-14]. Dostupno na: http://www2.hck.hr/hr/stranica/obiljezen-svjetski-dan-izbjeglica-20.lipnja-234.

15 Vidi Hrvatski Crveni križ. Pridružite nam se u obilježavanju Svjetskog dana izbjeglica! [ citirano: 2019-01-14]. Dostupno na: https://www.hck.hr/novosti/pridruzite-nam-se-uobiljezavanju-svjetskog-dana-izbjeglica/3517.

16 Vidi Ministarstvo unutarnjih poslova Republike Hrvatske. Colours of a Journey- crteži na temu prošlosti, sadašnjosti i budućnosti. [citirano: 2019-01-14]. Dostupno na: policija.hr/MainPu. aspx?id=273366.

17 Prema godišnjim Izvještajima o radu u Knjižnici Dugave od 2013. do 2018. godine. Izvještaji su dostupni u arhivi Knjižnice Dugave.

18 Prema Izvještaju o radu Knjižnice Dugave za 2018. godinu. 


\subsubsection{Aktivnosti za djecu i mlade}

Od sredine 2013. do kraja 2018. godine u suradnji s OŠ F. Galovića i I. OŠ Dugave, volonterima i članovima Hrvatskog Crvenog križa, Centra za mirovne studije, Isusovačke službe za izbjeglice, Udruge Knjiga u centru, Udruge Balkon i tražiteljima azila, održano je dvadeset čitaonica, šest predavanja te četiri kreativne radionice za naše najmlađe članove i djecu iz prihvatilišta. Ukupno je u organiziranim aktivnostima sudjelovalo preko 800 djece. Čitane su priče i održana predavanja o krajevima iz kojih najčešće dolaze tražitelji azila. Tako je u sklopu projekta KLJUČ do znanja kroz Akciju Čitomat, koja se provodi u Knjižnici Dugave, djeci iz Dječjeg vrtića Tratinčica, učenicima I. OŠ Dugave i OŠ Frana Galovića čitana dvojezična slikovnica Harun i Jasmin. Čitanju su pridodane fotografije starog i novog Damaska. ${ }^{19}$

U organizaciji i čitanju priča sudjelovali su i naši vanjski suradnici, profesori iz osnovnih škola, voditelji i volonteri Centra za mirovne studije, suradnici udruge Knjiga u centru, članovi Građanske inicijative Dugave, volonteri iz Isusovačke službe za izbjeglice i mnogi drugi. ${ }^{20}$

Tijekom petogodišnje suradnje, zajedno s tražiteljima azila i djelatnicima Hrvatskog Crvenog križa održane su četiri kreativne radionice za djecu na kojima su nas naši gosti, tražitelji azila, podučili tehnici transfera slike na platno. Ukrašavane su platnene torbe, majice i slike, izrađivani predmeti od novinskog papira, a u sklopu projekta Cronauti djeca su izrađivala čestitke za novogodišnje blagdane uz slatke poklone za djecu iz Prihvatilišta. Na taj način htjeli smo djeci iz lokalnih škola približiti druge kulture i upoznati ih s djecom iz drugih zemalja, a djeci tražitelja azila pomoći da prebrode traume ponekad koristeći radionice i kao radnu terapiju. ${ }^{21}$

\subsubsection{Aktivnosti za odrasle}

Zbog velikog interesa naših korisnika pokrenut je ciklus radionica učenja arapskog jezika. Radionice je vodio Issam Delwan, službeni prevoditelj Hrvatskog Crvenog križa. Od srpnja 2016. do kraja 2017. godine, kroz četiri ciklusa, održano je 30 radionica s 216 polaznika.

Projekt Književna senzibilizacija nastao je u suradnji s prevoditeljicom Ksenijom Banović iz Građanske inicijative Dugave. Cilj projekta koji je započeo u ožujku 2017. godine bio je senzibilizirati lokalno stanovništvo za novopridošle

19 Vidi Knjižnice grada Zagreba. Projekt Ključ do znanja. [citirano: 2019-01-14]. Dostupno na: http://www.kgz.hr/hr/dogadjanja/kljuc-do-znanja-42391/42391.

20 Vidi Centar za mirovne studije. Dugave pedaliraju i čitaju šarene priče. [citirano: 2019-01-14]. Dostupno na: https://www.cms.hr/azil-i-integracijske-politike/dugave-pedaliraju-i-citaju-sareneprice.

${ }^{21}$ Prema Izvještajima o radu u Knjižnici Dugave od 2013. do 2018. godine. Izvještaji su dostupni u arhivi Knjižnice Dugave. 
susjede, tražitelje azila, kroz književnost. Na susretima su se predstavljala književna djela koja tematiziraju problematiku migranata i azilanata s Bliskog istoka i iz Afrike. Kroz razgovor s književnicima, prevoditeljima, aktivistima i samim tražiteljima azila nastojalo se saznati više o tome tko su oni i odakle dolaze te može li nas književno djelo potaknuti da se zamislimo o sudbini tih ljudi i može li se na taj način pokrenuti njihova bolja socijalna uključenost u lokalnu zajednicu. ${ }^{22}$ Prvi susret održan je u ožujku 2017. godine pod naslovom „Iranom kroz književnost i astronomiju“, a u njemu su sudjelovali M. Katouzifar, azilantica, D. i S. Spanta iz Isusovačke službe za izbjeglice (JRS) i Antonijela Bogutovac, urednica Leksikografskog zavoda Miroslav Krleža. U travnju je uslijedio drugi susret, pod nazivom „Sirija u Dugavama“, na kojem smo ugostili Ivana Sršena iz izdavačke kuće Sandorf, Marka Šunjića iz izdavačke kuće Fibra, Hrvoja Ivančića, pisca i novinara, Tatjanu Paić Vukić, prevoditeljicu s arapskog i turskog jezika, Z. Saida, pisca i pjesnika te Issama Delwana, službenog prevoditelja s arapskog jezika za Hrvatski Crveni križ. ${ }^{23}$

Treći susret, naslovljen „Nigerijom kroz romane i putopis“, organiziran je u okviru Festivala priče „Afrička bajka“. U programu su sudjelovali P. W. Sonyaki iz Društva Afrikanaca u Hrvatskoj, Ivan Sršen iz nakladničke kuće Sandorf i Nermina Husković iz nakladničke kuće Hena.com. ${ }^{24}$

Krajem rujna 2017. godine održan je četvrti susret Književne senzibilizacije na kojem smo upoznali Pakistan. Sudionici susreta bili su Kristina Samardžić iz Isusovačke službe za izbjeglice (JRS) i K. Khan, tražitelj azila iz Pakistana (Balučistana). Na petom susretu predstavljen je Irak. Sudionici susreta bili su Nawar Ghanim Murad, knjižničarka Iva Bunčić i Dora Sivka iz Centra za mirovne studije. U lipnju 2018. godine održan je šesti susret u suradnji Knjižnice Dugave, Građanske inicijative Dugave i Hrvatskog centra PEN. Tema susreta bila je Somalija. U programu su sudjelovali Tomica Bajsić, pjesnik i predsjednik Hrvatskog P.E.N. centra i M. O. Gagale, gost iz Somalije. ${ }^{25}$ Projekt se nastavlja, a na sljedećim tribinama planira se predstaviti Afganistan, Egipat, Alžir, Maroko i Obalu Bjelokosti. Dosad je održano šest susreta Književne senzibilizacije koje je moderirala Ksenija Banović. Na njima su sudjelovala ukupno 174 posjetitelja.

22 Vidi Banović, K. Projekt Književne senzibilizacije u Knjižnici Dugave [citirano: 2019-01-14]. Dostupno na: https://www.irh.hr/izdvojeno/inicijative/514-projekt-knjizevne-senzibilizacije-uknjiznici-dugave.

23 Vidi Culturenet.hr. Književna senzibilizacija: Sirija u Dugavama. [citirano: 2019-01-14]. Dostupno na: https://www.culturenet.hr/default.aspx?id=76174.

24 Vidi Hrvatska volontira 2017. Književna senzibilizacija - Nigerija u Knjižnici Dugave. [citirano: 2019-01-14]. Dostupno na: htpps://hrvatska.volontira.vcz.hr/events/event/756.

25 Prema Izvještaju o radu Knjižnice Dugave za 2017. i 2018. godinu. Objava o događanju dostupna je na stranicama Jutarnjeg lista: https://www.jutarnji.hr/kultura/knjizevnost/gosti-izsomalije-u-knjiznici-dugave-nitko-ne-napusta-dom-osim-ako-dom-nisu-usta-morskog-psanapisala-je-slavna-somalska-pjesnikinja/7438923/. 


\subsubsection{Ostale aktivnosti}

Ujesen 2015. godine u suradnju s tražiteljima azila uključilo se i Američko veleposlanstvo svojom donacijom knjiga, slikovnica i brošura koje pomažu izbjeglicama da se lakše integriraju te prenošenjem iskustava iz SAD-a, gdje su knjižnice važan čimbenik u pružanju informacija i asimilaciji migranata i izbjeglica u lokalnu zajednicu. Isto tako, u Knjižnici Dugave kroz akciju Razmjena knjiga kontinuirano prikupljamo knjige na stranim jezicima, slikovnice i AV-građu te ih povremeno doniramo prihvatilištu. Godišnje se u Knjižnici Dugave prikupi i distribuira oko 3000 jedinica darovane građe. ${ }^{26}$

U knjižnici kontinuirano pripremamo tematske izložbe knjiga i ostale građe uz obljetnice iz kalendara događanja: Međunarodni dan tolerancije, Međunarodni dan ljudskih prava, Međunarodni humanitarni dan, Međunarodni dan volontera, Svjetski dan izbjeglica te redovno uz tribine Književne senzibilizacije, kada predstavljamo književnosti zemalja iz kojih najčešće dolaze tražitelji azila, a to su Iran, Sirija, Nigerija, Pakistan, Irak, Somalija i Afganistan. ${ }^{27}$

Nakon četiri godine suradnje s predstavnicima Hrvatskog Crvenog križa tijekom kojih smo dogovarali susrete i održavali radne dogovore u prostoru Knjižnice, krajem 2017. godine ukazala nam se prilika za organizirani posjet stručnih djelatnika Knjižnice Dugave i voditeljice novozagrebačke mreže Tihane Rašete prihvatilištu. Djelatnici Hrvatskog Crvenog križa upoznali su nas s prostorom Prihvatilišta, učionicama, knjižnicom, organizacijom rada u Prihvatilištu, smještajem te, ukratko, s postupcima prihvata tražitelja azila.

\subsubsection{Prikupljanje podataka o suradnji Knjižnice Dugave i tražitelja međuna- rodne zaštite}

Od sredine svibnja do sredine lipnja 2017. godine provedeno je anketiranje korisnika Knjižnice Dugave za znanstveno istraživanje „Odnos građana Zagreba prema integraciji azilanata i njihovim ljudskim pravima“. Voditelj istraživanja je Dean Ajduković s Odsjeka za psihologiju Filozofskog fakulteta u Zagrebu. ${ }^{28}$

Od svibnja 2017. do svibnja 2018. godine koordinatorica Knjižnice Dugave Sanja Lautenbach-Huzjak sudjelovala je u provođenju četiriju intervjua. Tijekom prvog intervjua u svibnju 2017. godine podatke za Ured za ljudska prava i prava

\footnotetext{
26 Podaci o doniranoj građi u akciji Razmjena knjiga u Knjižnici Dugave prikupljaju se tijekom kalendarske godine i prikazuju u godišnjim izvješćima o radu u Knjižnici Dugave. Izvještaji su dostupni u arhivi Knjižnice Dugave.

27 Izvještaj o radu u Knjižnici Dugave za 2017. godinu.

28 Vidi Ajduković, D.; H. Bakić.; N. Stanković; J. Matić. Odnos mladih prema integraciji azilanata. // Psihologija u promociji i zaštiti ljudskih prava i društvene pravednosti: sažetci priopćenja / Ćubela Adorić, Vera; Franc, Renata; Kalebić Maglica, Barbara; Nakić Radoš, Sandra (ur.). Zagreb: Hrvatsko psihološko društvo, 2017. Str. 63. [citirano: 2019-01-14]. Dostupno na: https://www.bib.irb.hr/906644.
} 
nacionalnih manjina te Europsku komisiju prikupljala je Ivana Đurić. Radilo se na evaluaciji integracijskog okvira migranata u Hrvatskoj za projekt „Potpora provedbi politike za integraciju migranata: izvješće o evaluaciji provedbenog okvira“. ${ }^{29}$ U lipnju 2017. godine podatke su prikupljale Andrea Rudan i Željka Jurlina iz Centra za mirovne studije, a u svrhu mapiranja zajednice Dugave. ${ }^{30}$

Intervjuiranjem ključnih aktera u Dugavama željelo se ispitati trenutačnu situaciju te saznati kakvi su preduvjeti za stvaranje pluralističke zajednice koju krase uzajamno prihvaćanje i dijalog između tražitelja azila i lokalnog stanovništva. ${ }^{31}$

Iva Bunčić iz Knjižnice Špansko-jug intervjuom je prikupljala podatke za pripremu diplomskog rada „Uloga knjižnica u socijalnoj integraciji marginaliziranih skupina s naglaskom na izbjeglice i romsku nacionalnu manjinu“. ${ }^{32}$

Krajem svibnja 2018. godine Dinka Čorkalo Biruški, predstojnica Katedre za socijalnu psihologiju na Odsjeku za psihologiju Filozofskog fakulteta u Zagrebu, intervjuirala je koordinatoricu Knjižnice Dugave Sanju Lautenbach-Huzjak za istraživanje o potrebama lokalnih zajednica za projekt „Podrška u integraciji stranih državljana kojima je u Republici Hrvatskoj odobrena međunarodna zaštita“. Istraživanje je provodio Ured za ljudska prava i prava nacionalnih manjina Vlade Republike Hrvatske. Razgovaralo se o postojećim ili mogućim aktivnostima i potrebama $u$ vezi s integracijom azilanata. Cilj istraživanja bio je izdvojiti primjere dobre prakse te predložiti preporuke za izgradnju i unapređivanje kapaciteta lokalnih zajednica kako bi se uspješnije nosile s izazovima integracije azilanata. ${ }^{33}$

\subsubsection{Prezentiranje suradnje Knjižnice Dugave i tražitelja međunarodne zaštite na stručnim skupovima}

Iskustva dobre prakse suradnje Knjižnice Dugave s tražiteljima međunarodne zaštite predstavljali smo na nekoliko stručnih skupova, a Pavel Vrbanc, kolegica iz Knjižnice Dugave, pisala je o suradnji knjižnice i tražitelja azila u članku „U po-

29 Prema e-poruci I. Đurić od 14.12. 2018. dovršen je izvještaj za koji su uz pisane izvore korišteni i intervjui. Integralni tekst evaluacijskog izvješća još nije dostupan na mrežnoj stranici korisničke institucije (Ured za ljudska prava i prava nacionalnih manjina Vlade $\mathrm{RH}$ ).

30 Vidi Centar za mirovne studije. Vjera u vlastite snage. [citirano: 2019-01-14]. Dostupno na: https://www.cms.hr/hr/novosti/vjera-u-vlastite-snage.

31 Prema e-poruci A. Rudan od 10. 12. 2018.

32 Nakon obrane rada autorica I. Bunčić dostavila nam je diplomski rad. Usp. Bunčić, I. Uloga knjižnice u socijalnoj integraciji marginaliziranih skupina s naglaskom na izbjeglice i romsku nacionalnu manjinu: diplomski rad. Zagreb: Filozofski fakultet Sveučilišta, 2017. Str. 10-12. [citirano: 2019-01-16]. Dostupno na: http://darhiv.ffzg.unizg.hr/id/eprint/9036/.

33 Usp. Ajduković, D.; D. Čorkalo Biruški; M. Gregurović; J. Matić Bojić; D. Župarić-Iljić. Završni izvještaj projekta Podrška integraciji državljana trećih zemalja kojima je potrebna međunarodna zaštita. Zagreb: Filozofski fakultet i Institut za migracije i narodnosti, 2018.; Prema e-poruci D. Čorkalo Biruški od 6. 12. 2018., istraživanje će u integralnom obliku biti objavljeno oko 15. siječnja 2019. 
trazi za novim domom: knjižnica kao mjesto susreta 'Nas' i 'Njih'“ koji je objavio Novi uvez: glasilo Zagrebačkog knjižničarskog društva. ${ }^{34}$

U prosincu 2017. godine koordinatorica Knjižnice Dugave Sanja Lautenbach-Huzjak sudjelovala je na 2. Okruglom stolu Knjižnice za druge i drugačije u Puli, s prezentacijom „Knjižnica Dugave kao mjesto susreta s drugim kulturama“, koja je pripremljena u suradnji s voditeljicom novozagrebačke mreže Tihanom Rašetom.

U travnju 2018. godine Tihana Rašeta i Sanja Lautenbach-Huzjak sudjelovale su na dvodnevnom tečaju „Stav o multikulturalizmu: i drugi ovdje pripadaju“ u okviru međunarodnog projekta Migrate to Library! u Gradskoj knjižnici u Zagrebu. Skup je priređen za projektne partnere iz Poljske, Španjolske i Litve. Edukaciju su održali stručnjaci iz CMS-a uz sudjelovanje osoba s migrantskim ili izbjegličkim iskustvom. ${ }^{35}$

U okviru međunarodnog susreta organiziran je i radni posjet Knjižnici Dugave od strane kolegica iz Gradske knjižnice Ivan Vidali iz Korčule i 14 stranih partnera iz Litve, Poljske i Španjolske. Uz razgovor i upoznavanje s knjižnicom prezentirali smo kolegama našu suradnju s tražiteljima azila iz Prihvatilišta Zagreb.

Posebno smo se osvrnuli na akcije koje kontinuirano održavamo na dječjem i odraslom odjelu, a tiču se senzibilizacije lokalnog stanovništva.

Dana 19. lipnja 2018. Tihana Rašeta i Sanja Lautenbach-Huzjak prisustvovale su panelu „Uključivanje djece tražitelja azila i nositelja međunarodne zaštite u odgojno-obrazovni sustav - analize politika i primjeri dobre prakse“. Panel je uoči Svjetskog dana izbjeglica organizirao Ured za ljudska prava i prava nacionalnih manjina Vlade Republike Hrvatske u Muzeju suvremene umjetnosti u Zagrebu. ${ }^{36}$

\subsection{Zaključak o dosadašnjoj suradnji Knjižnice Dugave i tražitelja me- đunarodne zaštite}

Tijekom proteklih pet godina suradnje održano je 85 raznih događanja za djecu i odrasle na kojima je sudjelovalo 1600 sudionika, što je izazvalo interes i potaknulo širu zajednicu na prikupljanje podataka za znanstvena istraživanja o odnosu građana prema integraciji azilanata te ulozi knjižnice u tom procesu.

Svakim novim susretom širila se mreža suradnika u planiranju budućih aktivnosti. Ostvarena je suradnja s 20 -ak institucija, među kojima se ističu: Hrvatski

34 God. 14., br. 26/2, prosinac 2016.

35 Vidi Hrvatsko knjižničarsko društvo. Program međunarodne radionice "Migrate to Library". [citirano: 2019-01-14]. Dostupno na: https://www.facebook.com/pg/HKDrustvo/posts/?ref=page internal.

36 Vidi Vlada Republike Hrvatske. Održan panel povodom Svjetskog dana izbjeglica. [citirano: 2019-01-14]. Dostupno na: https://judskaprava.gov.hr/vijesti/odrzan-panel-povodom-svjetskogdana-izbjeglica/810. 
Crveni križ, MUP, Prihvatilište za tražitelje azila Zagreb, OŠ Frana Galovića, I. OŠ Dugave, DV Tratinčica, Veleposlanstvo SAD-a, Centar za Mirovne studije, Građanska inicijativa Dugave, JRS - Isusovačka služba za izbjeglice, Udruga „Knjiga u centru“, Sandorf, Fibra, Društvo Afrikanaca u Hrvatskoj, Hena.com, Filozofski fakultet u Zagrebu, Odsjek za psihologiju, Ured za ljudska prava i prava nacionalnih manjina Vlade Republike Hrvatske, Vijeće gradske četvrti Novi Zagreb istok, Udruga „Balkon“, Gradska Knjižnica „I. Vidali“, Korčula, Hrvatski P.E.N. centar te šezdesetak pojedinaca, vanjskih suradnika.

Dobrim rezultatima suradnje svakako doprinosi entuzijazam i podrška svih naših vanjskih suradnika: djelatnika i volontera Hrvatskog Crvenog križa, Ministarstva unutarnjih poslova, Centra za mirovne studije, tražitelja azila koji su spremni javno dijeliti svoja iskustva, članica Građanske inicijative Dugave, profesora iz OŠ F. Galovića, I. OŠ Dugave, stručnog tima i odgajateljica iz DV Tratinčica, Isusovačke službe za izbjeglice, Udruge „Balkon“, pisaca, urednika, prevoditelja, voditeljice novozagrebačke mreže knjižnica te kolektiva Knjižnice Dugave.

\section{Zaključak}

Tema 43. Skupštine HKD-a održane od 10. do 13. 10. 2018. u Opatiji bila je „Uloga i mogućnosti knjižnica u ostvarivanju globalnih ciljeva održivog razvoja UN Agende 2030“.

Sudjelovanjem u radu Skupštine prezentacijom „Knjižnica Dugave kao mjesto susreta s drugim svjetovima“" autorice prezentacije, voditeljica novozagrebačke mreže knjižnica Tihana Rašeta i koordinatorica Knjižnice Dugave Sanja Lautenbach-Huzjak, imale su priliku upoznati sudionike s iskustvima i izazovima s kojima smo se susreli tijekom petogodišnje suradnje s novom skupinom naših korisnika, tražiteljima azila.

Moderatorica radne grupe na kojoj su prezentirane teme o Inkluzivnim knjižničnim uslugama Dijana Sabolović Krajina pozvala je sudionike nakon izlaganja na kratke zaključke o tome kako prezentirani programi doprinose ostvarivanju ciljeva UN Agende 2030.

Knjižnice su svojim aktivnostima i programskim okvirima već uključene u ostvarivanje svih globalnih ciljeva za održivi razvoj te potiču napredak na svim navedenim područjima UN Agende.

Programi i aktivnosti u okviru suradnje Knjižnice Dugave s tražiteljima međunarodne zaštite iz Prihvatilišta Zagreb otvoreni su za tražitelje međunarodne zaštite, korisnike svih dobnih skupina, aktiviste i volontere, članove raznih udruga i inicijativa te prijatelje knjižnice. Knjižnica i njezini stručni djelatnici, zajedno sa stvorenom mrežom suradnika koja se i dalje širi, sigurno doprinose i posebno podupiru Cilj 16 - Mir, pravda i snažne institucije: „Promovirati miroljubiva i uk- 
ljučiva društva za održivi razvoj, osigurati pristup pravdi za sve i izgraditi učinkovite, odgovorne i uključive institucije na svim razinama" te Cilj 17 - Partnerstvo za ciljeve: „Ojačati načine provedbe te učvrstiti globalno partnerstvo za održivi razvoj “. ${ }^{37}$ Narodne knjižnice, osim svoje osnovne djelatnosti kojom osiguravaju pristup znanju, informacijama i cjeloživotnom učenju, imaju vrlo važnu ulogu i kao nositelji promjena u društvu i lokalnoj zajednici. Organizacijom i provođenjem kulturnih i društvenih programa u knjižnici obogaćuje se društveni i kulturni život lokalne i društvene zajednice.

Danas su knjižnice suočene s mnogobrojnim promjenama koje se odnose na tehnički i informatički razvoj, ali svjedoče i velikim društvenim promjenama u svijetu. Jedna od njih svakako je i aktualna izbjeglička kriza tijekom koje su mnogi morali napustiti svoje domove i potražiti sigurnost u drugim zemljama, nadajući se kako će u njima nastaviti siguran život sa svojim obiteljima.

Pred lokalnu zajednicu i društvo u cjelini postavljeni su novi izazovi integracije stranaca u društvenu zajednicu. To je dinamičan, dvosmjeran proces međusobne prilagodbe kako stranaca tako i lokalnog stanovništva.

Knjižnica Dugave prihvatila je izazov te se u okviru svojih prostornih, programskih i ljudskih mogućnosti spremno odazvala pozivu na suradnju s ciljem poticanja aktivnijeg uključivanja tražitelja azila u zajednicu te senzibilizacije stanovništva u lokalnoj zajednici za novopridošle susjede.

Vjerujemo kako smo dosadašnjim aktivnostima u Knjižnici Dugave, provedenim u sklopu suradnje s tražiteljima azila iz Prihvatilišta Zagreb, zajedno sa sve širom mrežom vanjskih suradnika, potaknuli aktivnije uključivanje tražitelja azila u širu zajednicu, olakšali dvosmjeran proces međusobne prilagodbe tražitelja azila i lokalnog stanovništva te omogućili bolje razumijevanje kulturne raznolikosti naših novih sugrađana.

\section{LITERATURA}

Ajduković, D.; H. Bakić.; N. Stanković; J. Matić. Odnos mladih prema integraciji azilanata. // Psihologija u promociji i zaštiti ljudskih prava i društvene pravednosti: sažetci priopćenja / Ćubela Adorić, Vera; Franc, Renata; Kalebić Maglica, Barbara; Nakić Radoš, Sandra (ur.). Zagreb: Hrvatsko psihološko društvo, 2017. Str. 63. [citirano: 2019-01-14]. Dostupno na: https://www.bib.irb.hr/906644.

37 Vidi: Novi izazov: globalni ciljevi održivog razvoja do 2030 / priredila Pavić-Rogošić, L. Zagreb: ODRAZ, 2015. Str. 23-24. [citirano: 2019-01-14]. Dostupno na: www.odraz.hr/hr/ publikacije/publikacije/novi-izazov-globalni-ciljevi-odrzivog-razvoja-do-2030 
Banović, K. Projekt Književne senzibilizacije u Knjižnici Dugave [citirano: 2019-0114]. Dostupno na: https://www.irh.hr/izdvojeno/inicijative/514-projekt-knjizevne-senzibilizacije-u-knjiznici-dugave.

Bunčić, I. Uloga knjižnice u socijalnoj integraciji marginaliziranih skupina s naglaskom na izbjeglice i romsku nacionalnu manjinu: diplomski rad. Zagreb: Filozofski fakultet Sveučilišta, 2017. [citirano: 2019-01-16]. Dostupno na: http://darhiv.ffzg. unizg.hr/id/eprint/9036/.

Centar za mirovne studije. Dugave pedaliraju i čitaju šarene priče. [citirano: 2019-0114]. Dostupno na: https://www.cms.hr/azil-i-integracijske-politike/dugave-pedaliraju-i-citaju-sarene-price.

Centar za mirovne studije. Vjera u vlastite snage. [citirano: 2019-01-14]. Dostupno na: https://www.cms.hr/hr/novosti/vjera-u-vlastite-snage.

Culturenet.hr. Književna senzibilizacija: Sirija u Dugavama. [citirano: 2019-01-14]. Dostupno na: https://www.culturenet.hr/default.aspx?id=76174.

Dragović, F. Sigurnost europskih granica i migracije. Zagreb: Naklada Jesenski i Turk, 2018.

Grad Zagreb. Mjesni odbor Dugave. [citirano: 2019-01-14] Dostupno na: https://www. zagreb.hr/2-mjesni-odbor-dugave/14576.

Hrvatska volontira 2017. Književna senzibilizacija - Nigerija u Knjižnici Dugave. [citirano: 2019-01-14]. Dostupno na: htpps://hrvatska.volontira.vcz.hr/events/event/756.

Hrvatski Crveni križ. Obilježen Svjetski dan izbjeglica - 20. lipnja. [citirano: 2019.01-14]. Dostupno na: http://www2.hck.hr/hr/stranica/obiljezen-svjetski-dan-izbjeglica-20.-lipnja-234.

Hrvatski Crveni križ. Podrška tražiteljima međunarodne zaštite. [citirano: 2019-01-14]. Dostupno na: https://www.hck.hr/sto-radimo/azil-i-migracije/podrska-traziteljima-medjunarodne-zastite/210.

Hrvatski Crveni križ. Pridružite nam se u obilježavanju Svjetskog dana izbjeglica! [ citirano: 2019-01-14]. Dostupno na: https://www.hck.hr/novosti/pridruzite-nam-se-u-obiljezavanju-svjetskog-dana-izbjeglica/3517.

Hrvatsko knjižničarsko društvo. Program međunarodne radionice "Migrate to Library". [citirano: 2019-01-14]. Dostupno na: https://www.facebook.com/pg/HKDrustvo/posts/?ref=page internal.

Jutarnji list. Gosti iz Somalije u Knjižnici Dugave. [citirano: 2019-01-16]. Dostupno na: https://www.jutarnji.hr/kultura/knjizevnost/gosti-iz-somalije-u-knjiznici-dugave-nitko-ne-napusta-dom-osim-ako-dom-nisu-usta-morskog-psa-napisala-je-slavna-somalska-pjesnikinja/7438923/.

Grubiša, I. Mi i oni?: kulturnoantropološko propitivanje terenskog iskustva u Slavoniji. // Kamp, koridor, granica: studije izbjeglištva u suvremenom hrvatskom kontekstu / uredile Emina Bužinkić i Marijana Hameršak. Zagreb: Institut za etnologiju 
i folkloristiku: Centar za mirovne studije: Fakultet političkih znanosti: Centar za istraživanje etičnosti, državljanstva i migracija, 2017. Str. 59-79.

Kingsley, P. Nova Odiseja: priča o europskoj izbjegličkoj krizi. Zagreb: Profil knjiga, 2016.

Knjižnice grada Zagreba. Projekt Ključ do znanja. [citirano: 2019-01-14]. Dostupno na: http://www.kgz.hr/hr/dogadjanja/kljuc-do-znanja-42391/42391.

Lalić Novak, G.; R. Kraljević. Zaštita izbjeglica i ranjivih skupina migranata: priručnik za edukatore. Zagreb: Hrvatski Crveni križ, 2014. [citirano: 2019-01-09]. Dostupno na: https:/www.hck.hr/UserDocsImages/publikacije/Priru\%C4\%8Dnici/ Prirucnik\%20-\%20Zastita\%20izbjeglica\%20i\%20ranjivih\%20skupina\%20migranata.pdf.

Milardović, A. Uvodna riječ. // Stranci pred vratima Europe / urednik Anđelko Milardović Zagreb: Pan Liber: Institut za europske i globalizacijske studije, 2014. Str. 7-19.

Ministarstvo unutarnjih poslova Republike Hrvatske. Colours of a Journey- crteži na temu prošlosti, sadašnjosti i budućnosti. [citirano: 2019-01-14]. Dostupno na: policija.hr/MainPu.aspx?id=273366.

Ministarstvo unutarnjih poslova. Statistički pokazatelji osoba kojima je odobrena međunarodna zaštita u Republici Hrvatskoj zaključno do 30.09.2018. Str. 1. [citirano: 2019-01-14]. Dostupno na: http://stari.mup.hr/UserDocsImages/Publikacije/2018/19-10-Statisticki-pokazatelji-trazitelja- medunarodne-zastite-30-09.pdf.

Novi izazov: globalni ciljevi održivog razvoja do 2030 / priredila Pavić-Rogošić, L. Zagreb: ODRAZ, 2015. Str. 23-24. [citirano: 2019-01-14]. Dostupno na: www. odraz.hr/hr/publikacije/publikacije/novi-izazov-globalni-ciljevi-odrzivog-razvoja-do-2030.

Petrović, D. Izbjeglištvo u suvremenom svijetu: od političkoteorijskih utemeljenja do biopolitičkih ishoda. Zagreb : Naklada Ljevak, 2016.

Pristup i mogućnosti svima: kako knjižnice doprinose ostvarivanju Agende Ujedinjenih naroda za održiv razvoj 2030. Dostupno na: https://www.hkdrustvo.hr/hr/izdanja/ kategorija/elektronicka?fbclid=IwAR3OpnNa6NFN_n5yNBK-bXTtvb8AB0f5arjpm5gJG_xvg6tjiZJkJUreOMY.

Vlada Republike Hrvatske. Održan panel povodom Svjetskog dana izbjeglica. [citirano: 2019-01-14]. Dostupno na: https://judskaprava.gov.hr/vijesti/odrzan-panel-povodom-svjetskog-dana-izbjeglica/810.

Zakon o međunarodnoj i privremenoj zaštiti: pročišćeni tekst zakona: NN 70/15,127/17. // Zakon.hr. [citirano: 2019-01-16]. Dostupno na: https://www.zakon.hr/z/798/Zakon-o-me\%C4\%91unarodnoj-i-privremenoj-za\%C5\%A1titi.

\section{Ostali izvori:}

Izvještaji o radu Knjižnice Dugave za 2013., 2014., 2015., 2016., 2017. i 2018. godinu. 